\title{
Kajian Pemanfaatan IoT Berbasis LPWAN Untuk Jaringan Akuisisi Data ARG
}

\author{
Tri Istiana ${ }^{1 *}$, R. Yudha Mardyansyah ${ }^{2}$, G.S. Budhi Dharmawan ${ }^{3}$ \\ ${ }^{123}$ Pusat Jaringan Komunikasi Kedeputian Instrumentasi Kalibrasi Rekayasa Jaringan Komunikasi BMKG \\ *Corresponding Author, email : tri.istiana@ bmkg.go.id
}

\begin{abstract}
Abstrak - Salah satu parameter pengamatan unsur cuaca adalah jumlah curah hujan. Sistem pengamatan curah hujan salah satunya menggunakan ARG. Kondisi eksisting menggunakan IoT berbasis jaringan selular. Pada kajian ini peneliti mencoba memberikan alternatif sistem komunikasi untuk jaringan akuisisi data ARG menggunakan teknologi IoT berbasis LPWAN. Perbandingan dari tiga teknologi IoT LPWAN yang dapat diaplikasikan pada sistem komunikasi ARG yaitu NB-IoT, Sigfox dan LoRaWAN. Ketiga teknologi LPWAN telah mengikuti Peraturan Menteri Komunikasi dan Informatika Republik Indonesia Nomor 1 Tahun 2019. Ketiga teknologi tersebut dapat digunakan untuk jaringan akuisisi data ARG. Teknologi LoRaWAN pada daerah rural jangkauannya mencapai $20 \mathrm{~km}$. Perangkat LoRaWAN yang memenuhi syarat frekuensi telah dijual bebas di internet dengan band frekuensi $920 \mathrm{MHz}$ Dari ketiga teknologi ini, hanya LoRaWAN yang dapat digunakan untuk membangun jaringan komunikasi yang bersifat privat atau internal. Hal ini menjadi nilai lebih pada BMKG untuk membangun jaringan WAN LPWA skala kabupaten ataupun propinsi di wilayah yang terkendala dengan pengiriman data ARG melalui jaringan seluler.
\end{abstract}

Kata Kunci : IoT, LPWAN, ARG

Abstract_-One of parameters for observing weather elements is the amount of rainfall. The rainfall observation system is using ARG. The existing condition uses cellular network-based IoT. In this study, researchers tried to provide an alternative communication system for ARG data acquisition networks using LPWAN-based IoT technology. Comparison of three LPWAN IoT technologies that can be applied to ARG communication systems, namely NB-IoT, Sigfox, and LoRaWAN. The three LPWAN technologies have followed the Republic of Indonesia Minister of Communication and Information Regulation No. 1 of 2019. These three technologies can be used for ARG data acquisition networks. LoRaWAN technology in rural areas reaches $20 \mathrm{~km}$. LoRaWAN devices that meet frequency requirements have been sold freely on the internet with the $920 \mathrm{MHz}$ frequency band. Of these three technologies, only LoRaWAN can be used to build private or internal communication networks. This is an added value for BMKG to build district or provincial scale LPWA WAN networks in regions that are constrained by the transmission of ARG data through cellular networks.

Keyword : IoT, LPWAN, ARG

\section{(C) 2020 Elektron Jurnal Ilmiah}

\section{PENDAHULUAN}

Salah satu arah kebijakan BMKG adalah penguatan sistem operasional, termasuk didalamnya sistem jaringan komunikasi dan database di bidang meteorologi, klimatologi dan geofisika dalam rangka meningkatkan kualitas dan kuantitas produk informasi dan jasa meteorologi, klimatologi dan geofisika. Salah satu sasaran program dalam bidang klimatologi adalah meningkatkan kepuasan pengguna informasi iklim dan kualitas udara untuk mendukung ketahanan pangan, ketahanan energi dan pengurangan resiko bencana. Pengamatan unsur cuaca diperlukan untuk kebutuhan manusia yang dijadikan sebagai bahan untuk memprakirakan cuaca pada waktu yang akan datang dan juga cuaca lampau. Salah satu parameter pengamatan unsur cuaca adalah jumlah curah hujan. Sistem pengamatan curah hujan salah satunya menggunakan Automatic Rain Gauge (ARG).

Penakar hujan otomatis atau Automatic Rain Gauge (ARG) adalah peralatan yang digunakan untuk menghitung jumlah curah hujan dalam satuan waktu tertentu secara otomatis dengan bantuan baterai sebagai sumber tenaganya. Pengukuran curah hujan diukur secara akumulasi hingga 10 menit lamanya. Hasil pengukuran berupa data yang selanjutnya melalui sensor pada alat ini, terhubung dengan server di BMKG. Kondisi eksisting yang dilakukan di BMKG menggunakan IoT berbasis jaringan selular. Teknologi yang baik perlu didukung oleh komponen yang baik, begitu pula dengan teknologi Internet of Things (IoT). Sistem komunikasi yang digunakan untuk pengiriman data menggunakan kartu M2M. Data yang terkirim menggunakan kartu M2M akan ditampilkan dalam website awscenter.

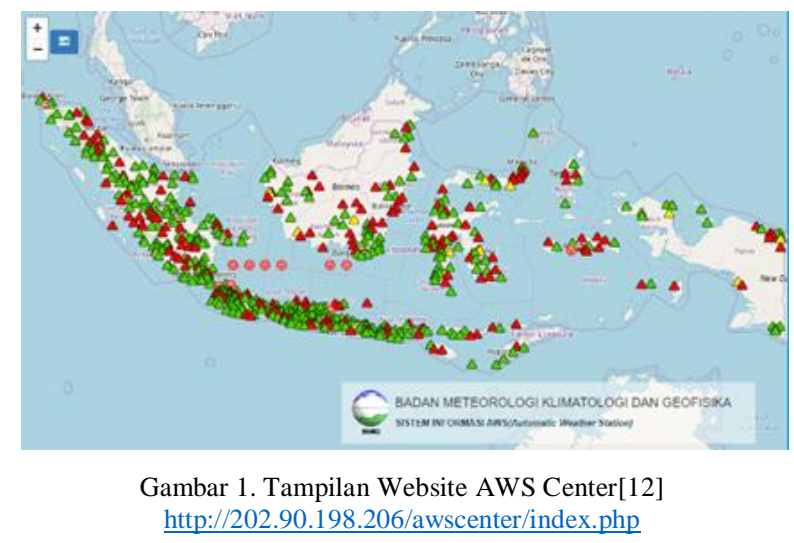

Penggunakan kartu M2M ini memiliki kelemahan data yang dikirim kecil yang mengakibatkan terjadinya inefisiensi basis seluler dan tidak semua lokasi tercakup dalam coverage jaringan seluler kartu M2M. Hal ini terjadi disalah satu lokasi pemasangan ARG di wilayah Propinsi Bali tepatnya di daerah Kintamani. Daerah Kintamani dengan ketinggian 1500 meter 
diatas permukaan laut. Akses yang bisa digunakan di daerah pemasangan Kintamani hanya kartu GSM dari salah satu provider hal ini menyulitkan karena banyak data yang tidak dapat terkirim ke BMKG Pusat. Oleh karena itu diperlukan teknologi yang dapat menutupi kelemahan dari penggunaan sistem komunikasi menggunakan kartu M2M.

Pada kajian ini peneliti mencoba memberikan suatu alternatif sistem komunikasi menggunakan teknologi IoT berbasis LPWAN untuk diaplikasikan pada ARG. Teknologi IoT berbasis LPWAN (Low Power Wide Area Non Seluller) memungkinkan pengguna untuk memantau, mengatur, dan melakukan pekerjaan lainnya melalui genggaman tangan. Semua hal tersebut dapat dilakukan karena semua komponen saling terhubung dan berkomunikasi melalui media internet dan menghubungkan perangkat IoT secara luas. Jumlah alat yang terhubung ke internet juga diperkirakan akan terus bertambah setiap tahun dalam jumlah yang besar. Teknologi IoT LPWAN menjadi salah satu jawaban atas permasalahan tersebut[3][12][13].Teknologi IoT berbasis LPWAN juga menjadi solusi dari penggunaan sistem komunikasi kartu M2M dimana teknologi IoT berbasis LPWAN memiliki keunggulan bernilai murah, berukuran kecil, dapat beroperasi dengan baterai dengan lifetime 5-10 tahun, dapat dioptimalkan untuk komunikasi dengan kecepatan data yang sangat kecil, mencakup semua wilayah yang terkoneksi dengan internet[2][3][11].

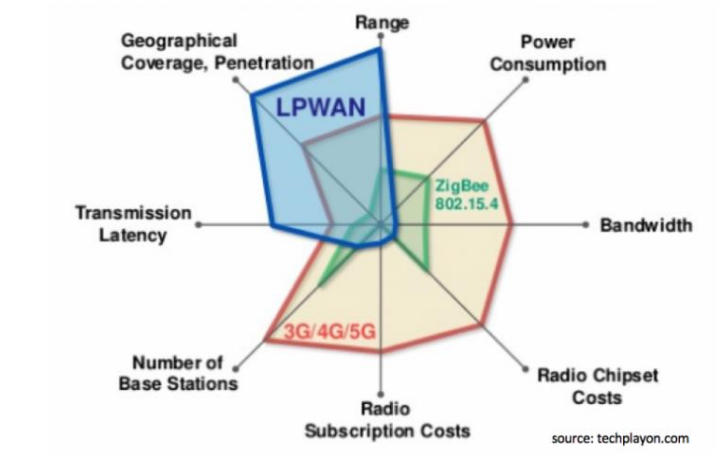

Gambar 2. Perbandingan karakteristik teknologi LPWAN dengan lainnya[11]

\section{STUDI LITERATUR}

\section{A. Dasar Hukum}

Peraturan Menteri Komunikasi dan Informatika Republik Indonesia Nomor 1 Tahun 2019 tentang Penggunaan Spektrum Frekuensi Radio Berdasarkan Izin Kelas telah mengatur penggunaan LPWAN Non Seluler di Indonesia[6]. Dalam peraturan tersebut dijelaskan bahwa Alat dan/atau Perangkat Telekomunikasi Low Power Wide Area Network Nonseluler yang selanjutnya disebut Alat dan/atau Perangkat Telekomunikasi LPWAN Nonseluler adalah Alat dan/atau Perangkat Telekomunikasi berdaya pancar rendah dengan cakupan luas yang beroperasi di luar Pita Frekuensi Radio untuk keperluan penyelenggaraan jaringan bergerak seluler. Sedangkan Izin Kelas adalah hak yang diberikan pada setiap orang perseorangan dan/atau badan hukum untuk dapat mengoperasikan suatu Perangkat Telekomunikasi yang menggunakan Spektrum Frekuensi Radio dengan syarat wajib memenuhi ketentuan teknis. Adapun pita frekuensi radio tersebut digunakan secara bersama (sharing) pada waktu, wilayah, dan/atau teknologi secara harmonis antar pengguna dan dilarang menimbulkan gangguan frekuensi radio yang merugikan serta tidak mendapatkan proteksi interferensi dari pengguna lain. Pita frekuensi radio yang diijinkan untuk operasional LPWAN Non seluler berada di rentang frekuensi 920 - $923 \mathrm{MHz}$.

\section{LPWAN}

Seiring dengan pesatnya perkembangan IoT, Low Power Wide Area Network (LPWAN) Non Seluler telah menjadi teknologi komunikasi radio yang semakin popular karena mempunyai karakteristik sebagai teknologi komunikasi jarak jauh yang lebih murah dengan daya rendah khususnya untuk pengiriman data kecil. Teknologi LPWAN dirancang untuk memberikan cakupan area yang luas. Hal ini didapat dengan menggunakan pita frekuensi dibawah 1 $\mathrm{GHz}$ (Sub-GHz band) dan teknik modulasi khusus. Penggunaan Sub-GHz band mempunyai kelebihan karena memiliki redaman propagasi yang lebih kecil dan beroperasi di wilayah frekuensi yang bukan wilayah sistem komunikasi radio pita lebar pada umumnya seperti Wi-Fi, Bluetooth, Wi-Max dan Broadband Wireless Access lainnya. Hal ini memberikan keuntungan dalam meminimalisir interferensi.

Teknologi modulasi yang digunakan LPWAN dirancang untuk mencapai link budget $150 \mathrm{~dB}$ sehingga mampu mencapai puluhan kilometer pada rural area. Mekanisme pengiriman data LPWA juga memberikan kelebihan dimana menjadikan perangkat pengguna dapat beroperasi dengan konsumsi daya rendah dan juga menurunkan biaya operasional.Teknologi LPWAN dapat dibagi menjadi 2 (dua) yaitu teknologi berbasis 3GPP dan teknologi proprietary atau non3GPP. Beberapa contoh teknologi 3GPP adalah LTEM, EC-GSM dan NB-IoT. Sedangkan contoh teknologi non-3GPP adalah SigFox, Ingenu RPMA, Wightless, dan LoRa WAN[5].

\section{NB IoT}

Narrowband internet of things (NB-IoT) adalah teknologi akses radio seluler baru-baru ini yang didasarkan pada Long-Term Evolution (LTE) yang diperkenalkan oleh Proyek Kemitraan Generasi Ketiga (3GPP) untuk Jaringan Low-Power Wide-Area (LPWA). Tujuan utama NB-IoT adalah untuk mendukung massive machine-type communication (mMTC) dan memungkinkan komunikasi tingkat daya rendah, berbiaya rendah, dan laju data kecil. NB-IoT dikategorikan sebagai salah satu teknologi seluler LowPower Wide-Area Networks (LPWAN). Istilah 
Narrowband mengacu pada bandwidth NB-IoT maksimum $200 \mathrm{kHz}$ yang dapat berdampingan dalam spektrum Global System for Mobile Communications (GSM) atau dengan menempati salah satu LTE Physical Resource Blocks (PRBs) sebagai in-band atau sebagai guard-band maupun standalone dalam lisensi spectrum frekuensi yang sama. Karena beroperasi berdampingan dalam spektrum LTE, NB-IoT juga mengikuti numerologi LTE karena menggunakan Orthogonal Frequency Division Multiplexing (OFDM) dan Single-Carrier Frequency Division Multiple Access (SC-FDMA) dalam skema transmisi downlink dan uplink dan menggunakan modulasi quadrature phaseshift keying (QPSK)[1].

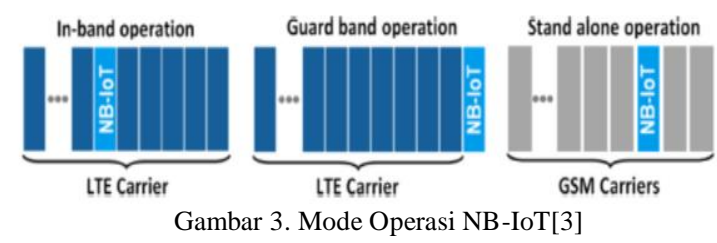

NB-IoT memungkinkan konektivitas hingga 100 ribu perangkat per sel dan berpotensi untuk meningkatkan kapasitas dengan menambahkan lebih banyak carrier NB-IoT. Kecepatan data dibatasi hingga 200 kbps untuk downlink dan 20 kbps untuk uplink. Ukuran payload maksimum untuk setiap pesan adalah 1600 byte. Teknologi NB-IoT dapat mencapai 10 tahun masa pakai baterai ketika rata-rata mentransmisikan 200 byte per hari[3].

\section{B. Sigfox}

Sigfox adalah operator jaringan LPWAN yang menawarkan mengakhiri solusi konektivitas IoT berdasarkan pada teknologi yang dipatenkannya. Sigfox menyebarkan dilengkapi stasiun induk eksklusifnya dengan radio yang ditentukan perangkat lunak kognitif dan menghubungkannya ke Internet server back end menggunakan jaringan berbasis IP. Perangkat akhir terkoneksi ke stasiun-stasiun induk ini menggunakan kunci-fase pengalihan biner (BPSK) modulasi dalam pita ultra-sempit $(100 \mathrm{~Hz})$ GHZ ISM band carrier. Sigfox menggunakan band ISM tanpa izin, untuk contoh, $868 \mathrm{MHz}$ di Eropa, $915 \mathrm{MHz}$ di Amerika Utara, dan $433 \mathrm{MHz}$ di Asia[3].

Menggunakan modulasi Ultra Narrow Band, Sigfox beroperasi pada $200 \mathrm{kHz}$ band yang tersedia untuk umum untuk bertukar pesan radio melalui udara. Setiap pesan berukuran lebar $100 \mathrm{~Hz}$ dan ditransfer pada kecepatan data 100 atau 600 bit per detik, tergantung pada wilayah. Oleh karena itu, jarak jauh dapat dicapai dengan kehandalan yang sangat kuat terhadap noise. Sigfox awalnya hanya mendukung komunikasi uplink, tetapi kemudian berkembang menjadi teknologi dua arah dengan asimetri tautan yang signifikan. Pesan uplink memiliki muatan hingga 12-byte dan mengambil rata-rata 2 detik di udara untuk mencapai stasiun pangkalan yang memantau spektrum mencari sinyal UNB untuk didemodulasi. Untuk payload data 12-byte, frame Sigfox akan menggunakan total 26 byte.
Payload yang diperbolehkan dalam pesan downlink adalah 8 byte[8]. Namun, jumlah pesan melebihi downlink dibatasi hingga empat pesan per hari, yang artinya konfirmasi dari setiap pesan uplink tidak didukung. Tanpa dukungan konfirmasi pesan yang memadai, keandalan komunikasi uplink dipastikan menggunakan waktu dan keragaman frekuensi serta duplikasi transmisi. Setiap pesan perangkat akhir dikirim beberapa kali (tiga kali oleh default) melalui saluran frekuensi yang berbeda. Untuk tujuan ini, di Eropa misalnya, pita antara 868.180 MHz dan 868.220 $\mathrm{MHz}$ dibagi menjadi 400 saluran $100 \mathrm{~Hz}$ ortogonal (di antara mereka 40 saluran dicadangkan dan tidak digunakan). Sebagai BTS dapat menerima pesan secara bersamaan di semua saluran, perangkat akhir dapat secara acak memilih frekuensi saluran untuk mengirimkan pesan mereka. Hal ini bertujuan untuk menyederhanakan desain perangkat akhir dan mengurangi biayanya[3].

Arsitektur datar Sigfox adalah kunci untuk meminimalkan CAPEX dan OPEX. Sigfox Software Defined Radio (SDR) membantu mengatasi biaya perangkat keras yang tinggi untuk BTS. Tidak ada perangkat keras khusus yang digunakan selain algoritma perangkat lunak untuk menangani demodulasi secara efektif. Ini mengurangi secara signifikan Total Biaya Operasi (TCO). Data dikirim melalui udara ke stasiun pangkalan, kemudian melewati backhaul. Backhaul umumnya menggunakan konektivitas DSL dan 3G atau 4G sebagai cadangan. Ketika salah satu dari keduanya tidak tersedia, konektivitas satelit dapat digunakan sebagai teknologi cadangan alternatif. Bagian belakang menangani pemrosesan pesan. Ada banyak kemungkinan replikasi dari pesan yang sama yang tiba di jaringan inti tetapi hanya satu yang harus disimpan. Server jaringan inti juga memonitor status jaringan dan mengelola stasiun pangkalan secara global.

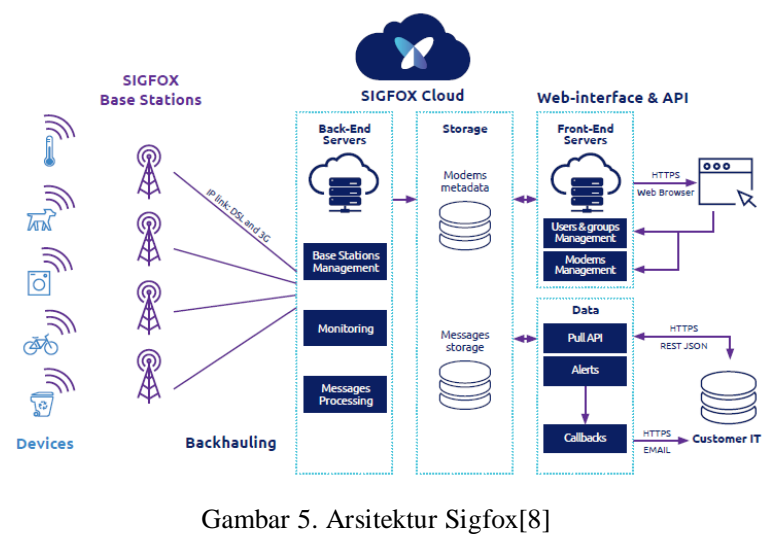

Infrastruktur jaringan juga menyimpan pesan di dua lokasi: metadata dapat digunakan untuk membangun layanan di satu sisi dan pesan pelanggan sehingga pelanggan dapat mengambilnya nanti di sisi lain. Akhirnya, antarmuka web dan API memungkinkan pelanggan untuk mengakses pesan mereka. Mereka dapat mengakses platform melalui browser web mereka atau menggunakan REST API 
untuk menyinkronkannya dengan sistem TI mereka dan mendorong pesan downlink ke perangkat[8].

\section{LORA}

LoRa adalah teknologi lapisan fisik yang memodulasi sinyal dalam sub-GHZ ISM band menggunakan teknik spread spectrum eksklusif. Seperti Sigfox, LoRa menggunakan pita ISM yang tidak berlisensi, yaitu, $868 \mathrm{MHz}$ di Eropa, $915 \mathrm{MHz}$ di Amerika Utara, dan $433 \mathrm{MHz}$ di Asia. Komunikasi dua arah disediakan oleh modulasi chirp spread spectrum (CSS) yang menyebar sinyal pita sempit melalui bandwidth saluran yang lebih luas. Sinyal yang dihasilkan memiliki tingkat kebisingan yang rendah, memungkinkan ketahanan interferensi yang tinggi, dan sulit dideteksi atau macet[3].

LoRa menggunakan enam faktor penyebaran (SF7 ke SF12) untuk mengadaptasi data rate dan range tradeoff. Faktor penyebaran yang lebih tinggi memungkinkan rentang yang lebih panjang dengan mengorbankan laju data yang lebih rendah, dan sebaliknya. Kecepatan data LoRa adalah antara 300 bps dan $50 \mathrm{kbps}$ tergantung pada faktor penyebaran dan bandwidth saluran. Selanjutnya, pesan yang dikirim menggunakan faktor penyebar yang berbeda dapat diterima secara bersamaan oleh BTS LoRa. Maximum payload untuk setiap pesan adalah sebesar 243 byte[3].

Protokol komunikasi berbasis LoRa yang disebut LoRaWAN telah distandarisasi oleh LoRa-Alliance (versi pertama pada tahun 2015). Menggunakan LoRaWAN, setiap pesan yang dikirim oleh perangkat akhir diterima oleh semua stasiun pangkalan dalam jangkauan. Dengan memanfaatkan penerimaan berlebihan ini, LoRaWAN meningkatkan rasio pesan yang berhasil diterima.

Dalam LoRaWAN TM node jaringan tidak terkait dengan gateway tertentu. Sebagai gantinya, data yang dikirimkan oleh suatu simpul biasanya diterima oleh banyak gateway. Setiap gateway akan meneruskan paket yang diterima dari end-node ke server jaringan berbasis cloud melalui beberapa backhaul (baik seluler, Ethernet, satelit, atau Wi-Fi) seperti yang terlihat pada gambar 6 .

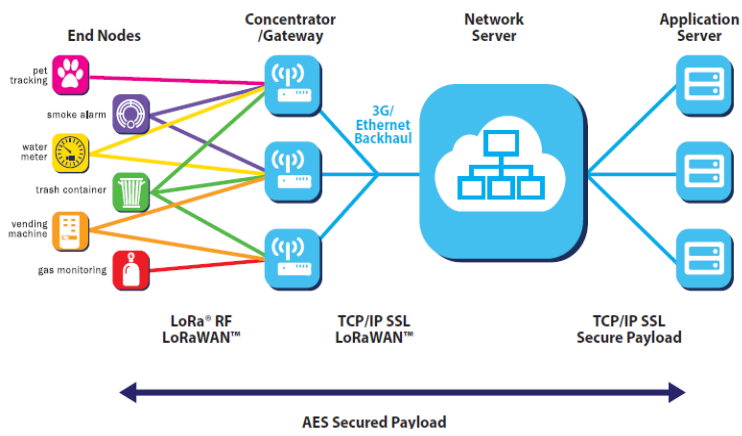

Gambar 6. Arsitektur LoRaWAN[7]

Kecerdasan dan kompleksitas didorong ke server jaringan, yang mengelola jaringan dan akan memfilter paket yang diterima berlebihan, melakukan pemeriksaan keamanan, menjadwalkan ucapan terima kasih melalui gateway optimal, dan melakukan kecepatan data adaptif, dll. Jika sebuah node bergerak atau bergerak ada tidak diperlukan penyerahan dari gateway ke gateway, yang merupakan fitur penting untuk mengaktifkan aplikasi pelacakan aset - aplikasi vertikal target utama untuk IoT.

\section{Perbandingan NB IoT, Sigfox dan LORA}

Perbandingan dari 3 teknologi IoT LPWAN yang dapat diaplikasikan pada sistem komunikasi ARG yaitu NB-IoT, Sigfox dan LoRaWAN. Spesifikasi teknis maupun fitur-fitur yang cocok untuk diaplikasikan pada sistem komunikasi ARG minimal termasuk coverage, payload length, frekuensi dan sifat jaringan.

Tabel 1. Perbandingan 3 teknologi IoT (Sigfox, LoRaWAN dan NB-IoT[3]

\begin{tabular}{|c|c|c|c|}
\hline & Sigfox & LoRaWAN & NB-IoT \\
\hline Modulation & BPSK & CSS & QPSK \\
\hline Frequency & $\begin{array}{l}\text { Unlicensed } \\
\text { ISM bands } \\
\text { (868 MHz di } \\
\text { Eropa, } 915 \\
\text { MHz di } \\
\text { Amerika } \\
\text { Utara dan } 433 \\
\text { MHz di Asia }\end{array}$ & $\begin{array}{l}\text { Unlicensed } \\
\text { ISM bands } \\
\text { ( } 868 \mathrm{MHz} \\
\text { di Eropa, } \\
915 \mathrm{MHz} \\
\text { di Amerika } \\
\text { Utara dan } \\
433 \mathrm{MHz} \\
\text { di Asia }\end{array}$ & $\begin{array}{l}\text { Licensed } \\
\text { LTE } \\
\text { (frequency } \\
\text { band) }\end{array}$ \\
\hline Bandwidth & $100 \mathrm{~Hz}$ & $\begin{array}{l}250 \mathrm{kHz} \\
\text { dan } 125 \\
\mathrm{kHz}\end{array}$ & $200 \mathrm{kHz}$ \\
\hline $\begin{array}{l}\text { Maksimum } \\
\text { data rate }\end{array}$ & $100 \mathrm{bps}$ & $50 \mathrm{kbps}$ & $200 \mathrm{kbps}$ \\
\hline Bidirectional & $\begin{array}{l}\text { Limited/Half- } \\
\text { duplex }\end{array}$ & $\begin{array}{l}\text { Ya/ Half } \\
\text { Duplex }\end{array}$ & $\begin{array}{l}\text { Ya/Half- } \\
\text { Duplex }\end{array}$ \\
\hline $\begin{array}{l}\text { Maksimum } \\
\text { message/hari }\end{array}$ & $\begin{array}{l}140 \text { (UL), } 4 \\
\text { (DL) }\end{array}$ & Unlimited & Unlimited \\
\hline $\begin{array}{l}\text { Maksimum } \\
\text { payload length }\end{array}$ & $\begin{array}{l}12 \text { bytes } \\
\text { (UL), } 8 \text { bytes } \\
\text { (DL) }\end{array}$ & 243 bytes & 1600 bytes \\
\hline Range & $\begin{array}{l}10 \mathrm{~km} \\
\text { (urban), } 40 \\
\mathrm{~km} \text { (rural) }\end{array}$ & $\begin{array}{l}5 \mathrm{~km} \\
\text { (urban), 20 } \\
\mathrm{km} \text { (rural) }\end{array}$ & $\begin{array}{l}1 \mathrm{~km} \\
\text { (urban), } 10 \\
\mathrm{~km} \text { (rural) }\end{array}$ \\
\hline $\begin{array}{l}\text { Interference } \\
\text { immunity }\end{array}$ & Sangat tinggi & $\begin{array}{l}\text { Sangat } \\
\text { tinggi }\end{array}$ & Rendah \\
\hline $\begin{array}{l}\text { Authentication } \\
\text { \& Encrytion }\end{array}$ & $\begin{array}{l}\text { Tidak } \\
\text { Support }\end{array}$ & $\begin{array}{l}\text { Yes (AES } \\
128 \mathrm{~b})\end{array}$ & $\begin{array}{l}\text { Ya (LE } \\
\text { encryption) }\end{array}$ \\
\hline $\begin{array}{l}\text { Adaptive data } \\
\text { rate }\end{array}$ & $\begin{array}{l}\text { Tidak } \\
\text { Support }\end{array}$ & Yes & Tidak \\
\hline Handover & $\begin{array}{l}\text { End- } \\
\text { Perangkat } \\
\text { tidak gabung } \\
\text { dengan single } \\
\text { base station }\end{array}$ & $\begin{array}{l}\text { End- } \\
\text { Perangkat } \\
\text { tidak } \\
\text { gabung } \\
\text { dengan } \\
\text { single base } \\
\text { station }\end{array}$ & $\begin{array}{l}\text { End- } \\
\text { Perangkat } \\
\text { gabung } \\
\text { dengan } \\
\text { single base } \\
\text { station }\end{array}$ \\
\hline Localization & Ya (RSSI) & $\begin{array}{l}\mathrm{Ya} \\
(\mathrm{TDOA})\end{array}$ & $\begin{array}{l}\text { Tidak (under } \\
\text { spesificaton) }\end{array}$ \\
\hline $\begin{array}{l}\text { Allow private } \\
\text { network }\end{array}$ & Tidak & $\mathrm{Ya}$ & Tidak \\
\hline Standar & $\begin{array}{l}\text { Sigfox } \\
\text { berkolaborasi } \\
\text { dengan ETSI } \\
\text { pada standar } \\
\text { jaringan } \\
\text { berbasis } \\
\text { Sigfox }\end{array}$ & $\begin{array}{l}\text { LoRa- } \\
\text { Alliance }\end{array}$ & $3 \mathrm{GPP}$ \\
\hline
\end{tabular}




\section{HASIL DAN PEMBAHASAN}

Pada umumnya site - site ARG BMKG mengirimkan data curah hujan setiap interval 10 menit. Data curah hujan yang dikirimkan berupa data ASCII dengan jumlah maksimal 5 karakter ASCII atau sekitar 5 Byte data.

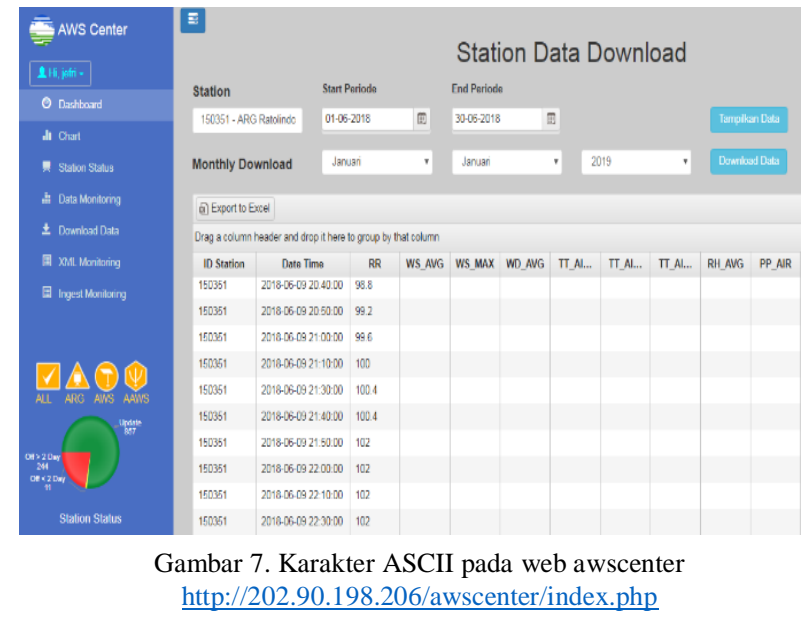

Dari ketiga teknologi komunikasi LPWA Non seluler tersebut, semuanya dapat digunakan untuk sistem komunikasi pengiriman data ARG.

Dari segi cakupan dimana banyak area blank spot sinyal GSM di wilayah timur Indonesia, teknologi SigFox sebenarnya sangat cocok dengan jangkauan sampai dengan $40 \mathrm{~km}$ pada daerah rural, hanya saja sistem komunikasi ini merupakan layanan operator jaringan yang memiliki lisensi sehingga sangat bergantung oleh infrastruktur yang akan dibangun oleh SigFox dan belum tentu tersedia di site - site ARG yang berada dalam wilayah non komersil bagi suatu operator jaringan komunikasi. SigFox di Indonesia baru saja melakukan ujicoba di tahun 2019 ini dan kemungkinan baru mulai beroperasi di tahun 2022[12]. Opsi lain yang cocok adalah menggunakan teknologi LoRaWAN dimana pada daerah rural jangkauannya dapat mencapai $20 \mathrm{~km}$.

Untuk penggunaan frekuensi diharuskan mengikuti Peraturan Menteri Komunikasi dan Informatika Republik Indonesia Nomor 1 Tahun 2019 tentang Penggunaan Spektrum Frekuensi Radio Berdasarkan Izin Kelas telah mengatur penggunaan LPWA Non Seluler di Indonesia yaitu pada rentang 920 - 923 $\mathrm{MHz}[6]$. Bagi operator jaringan seperti SigFox Indonesia dan Telkomsel yang sudah memulai ujicoba layanan NB-IoT[13]. Aturan penggunaan frekuensi LPWA Non seluler ini pasti akan dipatuhi. Adapun untuk perangkat LoRaWAN yang menggunakan open platform harus benar - benar selektif dalam pemilihan perangkat yang digunakan. Untuk teknologi LoRaWAN rentang frekuensi tersebut sudah masuk dalam standard frequency plan LoRaWAN AS920923[14]. Selain itu, perangkat LoRaWAN yang memenuhi syarat frekuensi tersebut sudah banyak dijual bebas di internet dengan band frekuensi 920
$\mathrm{MHz}$ [15]. Dengan demikian dari sisi kepatuhan terhadap penggunaan frekuensi, semua teknologi LPWA Non seluler baik NB-IoT, SigFox maupun LoRaWAN dapat digunakan untuk sistem komunikasi ARG.

Dari ketiga teknologi komunikasi LPWA non seluler ini, hanya LoRaWAN yang dapat digunakan untuk membangun jaringan komunikasi yang bersifat privat atau internal. Hal ini menjadi nilai lebih yang dapat memberikan fleksibilitas dan skalabilitas pada BMKG untuk dapat membangun jaringan WAN LPWA skala kabupaten atau pun propinsi di suatu wilayah yang terkendala dengan pengiriman data ARG melalui jaringan seluler. Selain itu, sistem pengiriman data LoRaWAN dari suatu end node yang memungkinkan untuk diterima secara bersamaan oleh lebih dari satu gateway dan ini sangat cocok dengan BMKG dimana pada suatu propinsi biasanya terdapat lebih dari satu UPT BMKG yang dapat menjadi gateway LoRaWAN. Hal ini dapat menjadi solusi bagi pemakaian kartu M2M dimana data yang dikirim kecil dan tidak semua lokasi tercakup dalam coverage jaringan seluler kartu M2M.

Gambar 8 dibawah ini menunjukkan penggambaran sistem ARG di BMKG menggunakan LPWAN teknologi LoRaWAN

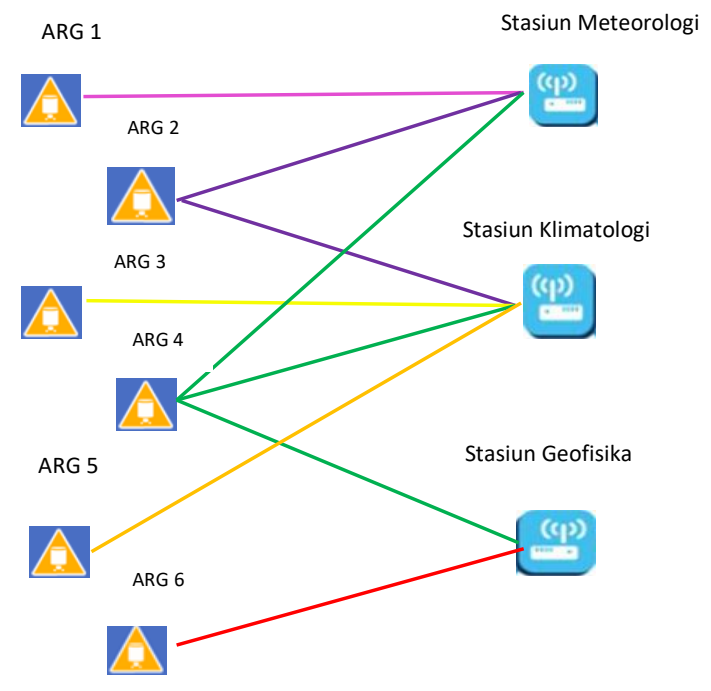

Gambar 8. Penggambaran sistem ARG menggunakan LPWAN teknologi LoRaWAN

\section{KESIMPULAN}

Teknologi Sigfox sangat cocok diimplementasikan di banyak area blank spot sinyal GSM di wilayah timur Indonesia dengan jangkauan sampai dengan $40 \mathrm{~km}$ pada daerah rural, tetapi sistem ini merupakan layanan operator jaringan yang memiliki lisensi sehingga tergantung pada infrastruktur yang dibangung oleh Sigfox yang belum tentu tersedia diwilayah non komersil. Ketiga teknologi LPWAN yaitu NB IoT, Sigfox dan LoRa telah memenuhi kepatuhan hukum terhadap penggunaan frekuensi sesuai dengan Peraturan Menteri Komunikasi dan Informatika 
Republik Indonesia Nomor 1 Tahun 2019 tentang Penggunaan Spektrum Frekuensi Radio Berdasarkan Izin Kelas telah mengatur penggunaan LPWAN Non Seluler di Indonesia ${ }^{8}$. Dari ketiga jenis LPWAN, LoRaWAN dapat digunakan untuk membangun jaringan komunikasi yang bersifat privat atau internal yang dibutuhkan oleh BMKG untuk membangun jaringan WAN skala kabupaten ataupun propinsi yang terkendala dengan pengiriman data ARG melalui jaringan seluler.

\section{Saran dan Rekomendasi}

Perlu dilakukan implementasi lebih lanjut pemanfaatan teknologi LoRaWAN untuk jaringan ARG di BMKG dan dilakukan kajian pemanfaatan teknologi LPWAN lainnya yang lebih konprehensif dengan bagian bagian terkait

\section{REFERENSI}

[1] C. B. Mwakwata , H. Malik , M. M. Alam , Y. Moullec, S Parand and S. Mumtaz, "Narrowband Internet of Things (NB-IoT): From Physical (PHY) and Media Access Control (MAC) Layers Perspectives", www.mdpi.com/journal/sensors, 2019

[2] J.P. Bardyn, T. Melly, O.Seller dan N. Somin, “ IoT : the Era of LPWAN is starting now," IEEE, 2016

[3] K. Mekkia, E. Bajica, F. Chaxela, F. Meyer, "A comparative study of LPWAN technologies for large-scale IoT deployment", Information \& Communications Technology Express Journal, Volume 5, Issue 1, March 2019

[4] K.E. Nolan, W. Guibene dan M.Y. Kelly, "An Evaluation Of Low Power Wide Area network Technologies For Internet Of Things," IEEE, 2016)

[5] U. Raza, P. Kulkarni, and M. Sooriyabandara, "Low Power Wide Area Networks: An Overview", IEEE Communications Surveys and Tutorials, 2017.

[6] Peraturan Menteri Komunikasi dan Informatika Republik Indonesia Nomor 1 Tahun 2019 tentang Penggunaan Spektrum Frekuensi Radio Berdasarkan Izin Kelas telah mengatur penggunaan LPWA Non Seluler di Indonesia

[7] LoRa Alliance, "A technical overview of LoRa and LoRaWAN", lora-alliance.org

[8] Sigfox Technology Overview", www.sigfox.com

[9] Nur Hayati, M.Suryanegara, “The IoT LoRa System Design for Tracking and Monitoring Patient with Mental Disorder", IEEE International Conference on Communication, Networks and Satellite (Comnetsat), 2017

[10] Mia Rosmiati, Moch. Fachru Rizal , Fitri Susanti Gilang Fahreza Alfisyahrin." Air pollution monitoring system using LoRa modul as transceiver system”.TELKOMNIKA, Vol.17, No.2, April 2019,pp. 586 592

[11] Norhafizah Ramli, Muhammad Mun'im Zabidi, Anuar Ahmad, Ivin Amri Musliman. "An open source LoRa based vehicle tracking system”. Indonesian Journal of Electrical Engineering and Informatics (IJEEI) Vol. 7, No. 2, June 2019, pp. 221 228

[12] Sinha, Rashmi Sharan, Wei, Yiqiao Hwang, Seung Hoon. "A survey on LPWA technology: LoRa and NB-IoT". ScienceDirect ICT Express 3 (2017) 14-21

[13] Haxhibeqiri, Jetmir, De Poorter, Eli, Moerman, Ingrid, Hoebeke, Jeroen. "A survey of LoRaWAN for IoT: From technology to application". Sensors (Switzerland). Volume 18 , issue 11.2018 